\title{
Effect of Pea and Spring Cereals Intercropping on Grain Yield and Crude Protein Content
}

\author{
Žydrè Kadžiulienè $\cdot$ Lina Šarūnaitė $\cdot$ Irena Deveikytė
}

received / primljeno: 31.05.2010. accepted / prihvaćeno: 08.10.2010.

(C) 2011 IFVC

\begin{abstract}
Summary: The advantage of intercropping is beneficial biological interactions between crops and their different use of growth resources. Our experiment aimed at investigating the effects of pea intercropping with cereals on the improvement of cereal supply with nitrogen and protein content in grain on a loamy soil in organic farming conditions. It was carried out during 2007-2009 at the Lithuanian Institute of Agriculture in Dotnuva. Pea (Pisum sativum L.) and spring wheat (Triticum aestivum L.), spring barley (Hordeum vulgare L.), oats (Avena sativa L.), and triticale (x Triticosecale Wittm.) were sown as intercrops 50:50 or as a sole crop. The results obtained during the experimental years showed that the productivity and quality of spring cereal sole crops or intercrops depended on the species of cereals and varied between different year's cultivation conditions. Grain productivity in some cases was estimated to be higher in the intercrops, however it was not stable in three experimental years. The protein content and yield in the grain of cereals grown in intercrops was positively affected by pea intercrops.
\end{abstract}

Key words: intercrop, pea, protein, spring cereal, yield

\section{Introduction}

The inclusion of legumes in crop rotations and intercrops can provide increased protein-rich yields and a more sustainable source of nitrogen, while on the other hand it saves cost by reducing the requirement for mineral nitrogen application (Anil et al. 1998, Crews \& Peoples 2004). In many countries, legume plants have recently been receiving increasing attention from researchers and growers (Hauggaard-Nielsen et al. 2009, Mariotti et al. 2009, Stoddard et al. 2009, Mikić et al. 2010). Pea (Pisum sativum L.) is the most common legume in crop rotations and quite productive in temperate conditions, as well as in Lithuania (Auskalnis 2001).

Being one of the most popular plants in the organic cropping system, pea provides high quality forage, rich in crude protein and mineral elements (Corre-Hellou \& Crozat 2005, Lauk \& Lauk 2008). However, it is not less important for its ability to accumulate atmospheric nitrogen, on which depends the state of the whole crop rotation and agroecosystem, and

Ž. Kadžiulienė $(\bowtie) \cdot$ L. Šarūnaitè · I. Deveikytè

Institute of Agriculture, Lithuanian Research Centre for Agriculture and Forestry, Instituto al. 1, Akademija, Kedainiai LT-58344, Lithuania

e-mail: zkadziul@1zi.lt possible farming benefit. Pea is productive as main crops, but its vines could also be useful as a nitrogen source (Tripolskaja et al. 2008). Various soils are suitable for pea cultivation, but the crop yields best on moderately heavy loam (Dovydaitis 1992). However, due to its biological characteristics, pea cultivation is not so simple. Although of more recent cultivars, pea-grown as a sole crop has some disadvantages - it is prone to severe lodging, which aggravates its harvesting and weed control. As a result, pea productivity is more dependent on proper soil and crop management (Auškalnis \& Dovydaitis 1998, Auškalnis \& Dovydaitis 1999, Maikštènienè \& Satkus 2000, Auškalnis 2001). When grown in a mixture, e.g. with spring barley (Hordeum vulgare L.), the crop does not lodge and in the conventional cropping system produces a grain yield of nearly $5 \mathrm{t} \mathrm{ha}^{-1}$ (Auškalnis \& Dovydaitis 2000). Intercropping of cereals and legumes is widely used in low-input agriculture because the mixture of nitrogen $\mathrm{N}$-fixing and non-N-fixing crop species provides complementarities in the utilization of resources, reduces weed pressure and sustains plant health (Hauggaard-Nielsen et al. 2003, Jensen et al. 2006). Mixing species in cropping systems may lead to a range of benefits that are expressed on various space and time scales, from a short-term increase in crop yield and quality, to long-term agroecosystem 
sustainability, up to societal and ecological benefits (Malezieux et al. 2009).

Our experiment aimed at investigating the effects of pea intercropping with cereals on the improvement of cereal supply with nitrogen and protein content in grain on a loamy soil in organic farming conditions.

\section{Materials and Methods}

The field experiment was carried out on a loamy Endocalcari-Epihypogleyic Cambisol during 2007-2009 at the Lithuanian Institute of Agriculture in Dotnuva $\left(55^{\circ} 24^{\prime} \mathrm{N}, 23^{\circ} 50 \mathrm{E}\right)$. The soil $\mathrm{pH}$ varied at about 7.5 , humus content was $2.3 \%$, available P $74-79 \mathrm{mg} \mathrm{kg}^{-1}$ and K 135 $140 \mathrm{mg} \mathrm{kg}^{-1}$. Wheat (Triticum aestivum L.), barley, oats (Avena sativa L.) and triticale (x Triticosecale Wittm.) were grown as sole crops and intercrops calculated according to the amount of nitrogen, by multiplying with 6.25 for pea and 5.7 for spring cereals. The LER values were calculated as follows (Mead \& Willey 1980):

$$
\mathrm{L}_{\mathrm{c}}=\frac{Y_{\text {cereallC }}}{Y_{\text {cerealsC }}} ; \mathrm{L}_{\mathrm{p}}=\frac{Y_{\text {pealC }}}{Y_{\text {peasC }}}
$$

and LER $=\mathrm{L}_{\mathrm{c}}+\mathrm{L}_{\mathrm{p}} . Y_{\text {cereal IC }}$ and $Y_{\text {peaIC }}$ are the intercrop yields and $Y_{\text {cerealsc }}$ and $Y_{\text {peasc }}^{\text {pealc }}$ are the sole crop yields of cereal and pea respectively. A LER value above one indicates a benefit of intercropping.

The experimental data were processed by analysis of variance (ANOVA) applying Least Significant Difference (LSD) test using the computer software Selekcija (Tarakanovas \& Raudonius 2003).

Table 1. Temperature and precipitation during the winter and growing period

Tabela 1. Temperatura i padavine tokom zime i vegetacionog perioda

\begin{tabular}{|c|c|c|c|c|c|c|c|c|}
\hline \multirow[t]{2}{*}{$\begin{array}{l}\text { month } \\
\text { mesec }\end{array}$} & \multicolumn{3}{|c|}{$\begin{array}{l}\text { mean air temperature / } \\
\text { srednja temperatura vazduha } \\
\left({ }^{\circ} \mathrm{C}\right)\end{array}$} & \multirow[t]{2}{*}{$\begin{array}{l}1924- \\
2009\end{array}$} & \multicolumn{3}{|c|}{$\begin{array}{l}\text { precipitation per month / } \\
\text { mesečna suma padavina } \\
(\mathrm{mm})\end{array}$} & \multirow[t]{2}{*}{$\begin{array}{l}1924 \\
- \\
2009\end{array}$} \\
\hline & 2007 & 2008 & 2009 & & 2007 & 2008 & 2009 & \\
\hline January & 1.0 & 0.5 & -2.8 & -4.8 & 88.3 & 68.8 & 41.0 & 30.2 \\
\hline February & -7.4 & 2.2 & -3.5 & -4.5 & 25.7 & 31.1 & 18.7 & 25.3 \\
\hline March & 5.2 & 2.6 & 0.9 & -0.8 & 23.6 & 53.4 & 53.9 & 28.5 \\
\hline April & 6.9 & 8.8 & 8.8 & 5.8 & 15.8 & 38.7 & 13.1 & 36.9 \\
\hline May & 13.5 & 12.2 & 12.7 & 12.2 & 98.2 & 13.2 & 26.7 & 51.8 \\
\hline June & 17.6 & 16.1 & 14.6 & 15.6 & 61.5 & 49.2 & 168.6 & 62.4 \\
\hline July & 17.2 & 18.2 & 18.1 & 17.6 & 118.1 & 47.6 & 90.0 & 73.4 \\
\hline August & 18.7 & 18.0 & 16.8 & 16.7 & 50.8 & 90.8 & 67.1 & 73.7 \\
\hline September & 12.8 & 12.1 & 13.9 & 12.0 & 49.1 & 16.0 & 48.2 & 51.3 \\
\hline October & 7.7 & 8.9 & 5.2 & 6.8 & 48.7 & 80.4 & 95.4 & 50.2 \\
\hline
\end{tabular}

data by Dotnuva meteorology station / podaci meteorološke stanice Dotnuva

with field pea. The experimental plots were laid out in a complete one-factor randomised block design in three replicates. The intercrop design was based on the proportional replacement principle, with mixed pea grain and spring cereals grain at the same depth in the same rows at relative frequencies of 50:50. Wheat seeds rates were calculated on the basis of 5.5 , barley 4.7 , oat 6.0, triticale 4.5 and pea 1.0 million seeds ha ${ }^{-1}$ for sole crop. The crops were cultivated according to organic management practices.

The crops were harvested at complete maturity stage. Grain yield components were determined from plant samples taken before harvest. Grain dry matter (DM) yield was determined after threshing. Nitrogen was determined by Kjeldahl, while crude protein content was
The precipitation sums and the temperature means during experimental period are shown in table 1.

\section{Results and Discussion}

The number of the productive stems was significantly lower in the intercrops than in sole peas or cereals (Tab. 2) in all three years of experiment and naturally fluctuated between years. Number of pea grain in intercrops was also lower, therefore number of cereals grain per ear was higher in intercrops and number of wheat and triticale was significantly higher. In previous research on pea productivity on light loam soil, it was noticed that a stand density of $80-90$ plants $\mathrm{m}^{-2}$ was sufficient to produce a rather high yield (Auškalnis \& Dovydaitis 1998). 
Table 2. The grain yield components in pea and spring cereals crop structure

Tabela 2. Komponente prinosa zrna u strukturi useva stočnog graška i jarih strnih žita

\begin{tabular}{|c|c|c|c|c|c|c|c|c|c|}
\hline \multirow[t]{2}{*}{$\begin{array}{l}\text { treatment } \\
\text { varijanta }\end{array}$} & \multicolumn{3}{|c|}{$\begin{array}{l}\text { number of productive } \\
\text { stems } \\
\text { broj produktivnih stabala } \\
\left(\mathrm{m}^{-2}\right)\end{array}$} & \multicolumn{3}{|c|}{$\begin{array}{l}\text { grain number } \\
\text { per ear/legume stem } \\
\text { broj zrna po klasu/stablu } \\
\left(\mathrm{m}^{-2}\right)\end{array}$} & \multicolumn{3}{|c|}{$\begin{array}{l}\text { thousand grain weight } \\
\text { masa } 1000 \text { zrna } \\
\text { (g) }\end{array}$} \\
\hline & 2007 & 2008 & 2009 & 2007 & 2008 & 2009 & 2007 & 2008 & 2009 \\
\hline \multicolumn{10}{|c|}{$\begin{array}{c}\text { pea + wheat } \\
\text { grašak }+ \text { pšenica }\end{array}$} \\
\hline $\begin{array}{l}\text { pea } \\
\text { grašak }\end{array}$ & 48 & 50 & 46 & 10 & 9 & 7 & 219 & 221 & 196 \\
\hline $\begin{array}{l}\text { wheat } \\
\text { pšenica }\end{array}$ & 367 & 227 & 300 & 39 & 42 & 40 & 39 & 40 & 28 \\
\hline \multicolumn{10}{|c|}{$\begin{array}{c}\text { pea }+ \text { barley } \\
\text { grašak + ječam }\end{array}$} \\
\hline $\begin{array}{l}\text { pea } \\
\text { grašak }\end{array}$ & 38 & 50 & 32 & 8 & 9 & 6 & 111 & 108 & 213 \\
\hline $\begin{array}{l}\text { barley } \\
\text { ječam }\end{array}$ & 305 & 215 & 357 & 23 & 19 & 24 & 52 & 48 & 44 \\
\hline \multicolumn{10}{|c|}{$\begin{array}{c}\text { pea }+ \text { oat } \\
\text { grašak }+ \text { ovas }\end{array}$} \\
\hline $\begin{array}{l}\text { pea } \\
\text { grašak }\end{array}$ & 57 & 64 & 52 & 9 & 11 & 5 & 199 & 215 & 195 \\
\hline oat & 311 & 198 & $\underset{\text { gra }}{266}$ & $\begin{array}{l}48 \\
a+\text { triti } \\
\text { ak }+ \text { tri }\end{array}$ & 48 & 60 & 28 & 36 & 33 \\
\hline $\begin{array}{l}\text { pea } \\
\text { grašak }\end{array}$ & 46 & 42 & 56 & 13 & 8 & 8 & 227 & 219 & 223 \\
\hline $\begin{array}{l}\text { triticale } \\
\text { tritikale }\end{array}$ & 279 & 197 & 239 & 44 & 44 & 49 & 38 & 40 & 40 \\
\hline \multicolumn{10}{|c|}{ sole crops / pojedinačni usevi } \\
\hline $\begin{array}{l}\text { pea } \\
\text { grašak }\end{array}$ & 126 & 99 & 102 & 20 & 13 & 15 & 239 & 220 & 233 \\
\hline $\begin{array}{l}\text { wheat } \\
\text { pšenica }\end{array}$ & 584 & 327 & 522 & 33 & 36 & 37 & 36 & 38 & 31 \\
\hline $\begin{array}{l}\text { barley } \\
\text { ječam }\end{array}$ & 462 & 338 & 395 & 21 & 21 & 25 & 45 & 50 & 43 \\
\hline $\begin{array}{l}\text { oat } \\
\text { ovas }\end{array}$ & 499 & 373 & 454 & 44 & 40 & 46 & 28 & 39 & 34 \\
\hline $\begin{array}{l}\text { triticale } \\
\text { tritikale }\end{array}$ & 415 & 307 & 382 & 38 & 38 & 46 & 36 & 37 & 37 \\
\hline \multicolumn{10}{|c|}{$\mathrm{LSD}_{0.05}$} \\
\hline $\begin{array}{l}\text { pea } \\
\text { grašak }\end{array}$ & 10.6 & 9.86 & 11.8 & 1.74 & 2.52 & 2.05 & 0.59 & 1.92 & 20.4 \\
\hline $\begin{array}{l}\text { spring cereal } \\
\text { jara strna žita }\end{array}$ & 42.2 & 43.7 & 63.3 & 4.51 & 4.65 & 3.24 & 1.60 & 0.19 & 0.26 \\
\hline
\end{tabular}

The results obtained during the tree experimental years showed that the productivity of spring cereal sole crops or cereal and pea intercrops depended on the species of cereals and cultivation conditions (Tab. 3).

The productivity of spring wheat and barley intercrops in the 2007 was significantly higher compared with that of the other intercrops and cereal sole crops, except for spring wheat (Tab. 3). The fact that intercropping of legumes and cereals produced higher yields than sole cereal crops without nitrogen fertilization was noticed by several researchers (Jensen 1996, Lauk \& Lauk 2005). The cultivation conditions were different in experimental years, therefore the results varied. In the year 2008, yields of cereal intercrops were lower than in the 2007, because the climatic conditions were droughty in the summer of 2008. Oat and pea intercrop grain yield was the highest and the productivity of barley intercrop was insignificantly lower compared with the other intercrops. In 2009, yields of cereal intercrops were lower than in the 2007, however higher than in 2008. In 2009, the intercrops were more 
Table 3. Grain yield and crude protein content and yield in intercrops and in sole pea or spring cereals Tabela 3. Prinos zrna i sadržaj i prinos sirovih proteina u združenom i čistom usevu stočnog graška i jarih strnih žita

\begin{tabular}{|c|c|c|c|c|c|c|c|c|c|}
\hline \multirow[t]{2}{*}{$\begin{array}{l}\text { treatment } \\
\text { varijanta }\end{array}$} & \multicolumn{3}{|c|}{$\begin{array}{l}\text { grain yield } \\
\text { prinos zrna } \\
\left(\mathrm{kg} \mathrm{ha}^{-1}\right)\end{array}$} & \multicolumn{3}{|c|}{$\begin{array}{l}\text { crude protein content } \\
\text { sadržaj sirovih proteina } \\
(\%)\end{array}$} & \multicolumn{3}{|c|}{$\begin{array}{l}\text { crude protein yield } \\
\text { prinos sirovi proteini } \\
\left(\mathrm{kg} \mathrm{ha}^{-1}\right)\end{array}$} \\
\hline & & 2008 & 2009 & & 2008 & 2009 & 2007 & 2008 & 2009 \\
\hline $\begin{array}{l}\text { peas+wheat } \\
\text { grašak+pšenica }\end{array}$ & 4491 & 2139 & 2225 & 16.1 & 14.5 & 14.3 & 689 & 311 & 319 \\
\hline $\begin{array}{r}\text { peas } \\
\text { grašak }\end{array}$ & 722 & 559 & 369 & 22.9 & 23.1 & 23.7 & 165 & 130 & 88 \\
\hline $\begin{array}{l}\text { wheat } \\
\text { pšenica }\end{array}$ & 3769 & 1580 & 1854 & 13.9 & 11.6 & 12.4 & 524 & 181 & 231 \\
\hline $\begin{array}{l}\text { pea+ barley } \\
\text { grašak+ječam }\end{array}$ & 3951 & 1851 & 2448 & 16.7 & 15.7 & 12.3 & 611 & 291 & 302 \\
\hline $\begin{array}{l}\text { peas } \\
\text { grašak }\end{array}$ & 649 & 783 & 265 & 23.1 & 22.4 & 23.6 & 150 & 175 & 63 \\
\hline $\begin{array}{l}\text { barley } \\
\text { ječam }\end{array}$ & 3302 & 1068 & 2183 & 14.0 & 10.8 & 11.0 & 461 & 116 & 239 \\
\hline $\begin{array}{l}\text { pea }+ \text { oat } \\
\text { grašak }+ \text { ovas }\end{array}$ & 3010 & 2379 & 2277 & 15.2 & 13.8 & 11.9 & 423 & 332 & 271 \\
\hline $\begin{array}{r}\text { peas } \\
\text { grašak }\end{array}$ & 634 & 514 & 188 & 23.4 & 23.6 & 22.8 & 150 & 121 & 43 \\
\hline $\begin{array}{r}\text { oat } \\
\text { ovas }\end{array}$ & 2376 & 1865 & 2089 & 11.5 & 11.4 & 10.9 & 275 & 211 & 228 \\
\hline $\begin{array}{l}\text { pea+triticale } \\
\text { grašak+tritikale }\end{array}$ & 3567 & 2089 & 2549 & 18.1 & 13.2 & 14.6 & 545 & 275 & 374 \\
\hline $\begin{array}{r}\text { peas } \\
\text { grašak }\end{array}$ & 838 & 414 & 310 & 23.0 & 22.9 & 23.3 & 193 & 96 & 72 \\
\hline $\begin{array}{l}\text { triticale } \\
\text { tritikale }\end{array}$ & 2729 & 1675 & 2239 & 12.9 & 10.9 & 13.5 & 352 & 179 & 302 \\
\hline \multicolumn{10}{|c|}{ sole crops / pojedinačni usevi } \\
\hline $\begin{array}{l}\text { pea } \\
\text { grašak }\end{array}$ & 4232 & 2342 & 2236 & 22.7 & 23.3 & 23.6 & 960 & 549 & 530 \\
\hline $\begin{array}{l}\text { wheat } \\
\text { pšenica }\end{array}$ & 4650 & 2210 & 2149 & 11.3 & 10.1 & 11.6 & 527 & 247 & 249 \\
\hline $\begin{array}{l}\text { barley } \\
\text { ječam }\end{array}$ & 3304 & 2114 & 2332 & 12.8 & 9.50 & 10.4 & 421 & 181 & 242 \\
\hline $\begin{array}{l}\text { oat } \\
\text { ovas }\end{array}$ & 3241 & 2924 & 2526 & 11.1 & 10.6 & 10.0 & 359 & 268 & 253 \\
\hline $\begin{array}{l}\text { triticale } \\
\text { tritikale }\end{array}$ & 3773 & 2341 & 2039 & 11.6 & 9.80 & 12.0 & 439 & 257 & 245 \\
\hline$* \mathrm{LSD}_{0.05}$ & 373.7 & 565.8 & 275.4 & 1.04 & 0.94 & 0.96 & 61.5 & 125.0 & 70.6 \\
\hline
\end{tabular}

*for total yield / za ukupni prinos

productive than sole cereal crops, except pea and oat intercrop and the most productive was pea and triticale intercrop. Some researchers noted that the yield of the intercrops was more stable than that of sole crops (Corre-Hellon et al. 2006). In our experiment, pea and barley intercrop in two years out of three produced higher yield compared with the sole barley crop, however we could not conclude that this intercrop yielded more stably.

Even in organic agriculture it is difficult to obtain comparative values for protein contents of different cereals. Analysis of data showed that crude protein concentration of the intercropped cereals was improved compared to sole cereal crops in all experimental years, but was estimated lower than in sole pea (Tab. 3). Differences in protein content in different cereals were recorded. The highest positive influence was achieved for intercropped triticale grain. In all three experimental years, protein concentration was significantly higher than that in sole triticale. The lowest influence was observed in intercropped oat and the protein concentration was insignificantly higher than that in sole oat. 

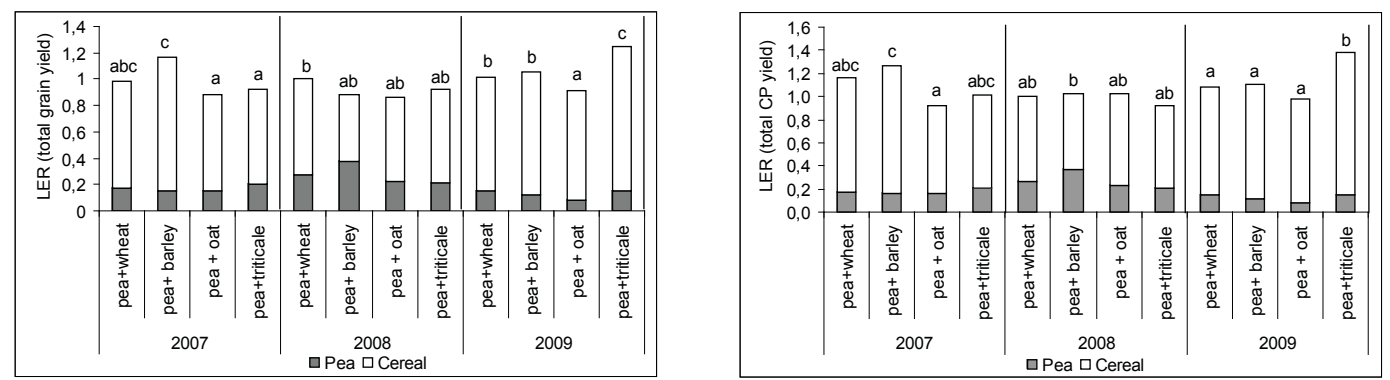

Fig. 1. Land equivalent ratio (LER) for pea-cereal intercrops based on grain and crude protein yields Slika 1. Površinski ekvivalentni odnos (LER) za združeni usev graška i pšenice zasnovan na prinosu sirovih proteina

The yield of crude protein in the intercrops varied between experimental years. Although the protein yield depended greatly on grain yield of crops, the yield of crude protein was determined to be lower in crops in 2008 and 2009 than in 2007. However, the yield of crude protein was increased in pea and cereal intercrops compared with cereal sole crops. Jensen et al. (2006) indicated that intercropping proved especially valuable for the production of protein on land with weed problems and for enhancing the grain protein concentration in cereals to levels, which were only likely to be obtained with high levels of animal manure.

The efficiency of resource use in intercropping relative to sole crop from interropping expose LER values (Fig. 1) based on grain yield. Total LERs above 1.00 were found in case of barley in 2007 and 2009, of wheat in 2009 and of triticale in 2009 intercrops, which shows the advantage of these mixtures over sole crops. Other cases in terms of total LER showed some disadvantage of intercrops. LERs calculations based on crude protein yield strengthen demonstrate that intercrops produce more per area than its sole cereal crops.

\section{Conclusions}

The productivity of spring cereal sole crops or pea and cereal intercrops depended on the species of cereals and varied depending on different year's cultivation conditions. Grain productivity in some cases was estimated to be higher in intercrops, however it could not be concluded that pea/cereals intercrops yielded stably in three experimental years. However, protein content in the grain of cereals grown in intercrops was positively affected by pea and cereal intercrops. Pea-cereal intercrops can increase land use productivity.

\section{References}

Anil L, Park J, Phipps R H, Miller F A (1998): Temperate intercropping of cereals for forage: a review of the potential for growth and utilization with particular reference to the UK. Grass Forage Sci. 53: 301-317

Auškalnis A, Dovydaitis V (1999): Productivity of different pea varieties (in Lithuanian with English abstract). ZemdirbysteAgriculture 68: 90-103

Auskalnis A (2001): Influence of sowing depth on productivity of peas on sandy loam soil (in Lithuanian with English abstract). Zemdirbyste-Agriculture 74: 105-111

Auškalnis A, Dovydaitis V (1998): The dependence of pea crop density and productivity on seed rate and sowing time on the light loam (in Lithuanian with English abstract). Žemdirbyste-Agriculture 63: 143-155

Auškalnis A, Dovydaitis V (2000): Productivity of pea, barley and their mixtures and the relationship between the grain protein content and nitrogen fertiliser and nitragine (in Lithuanian with English abstract). Zemdirbystè-Agriculture 69: 33-55

Corre-Hellou G, Crozat Y (2005): $\mathrm{N}_{2}$ fixation and $\mathrm{N}$ supply in organic pea (Pisum sativum L.) cropping systems as affected by weeds and peaweevil (Sitona Lineatus L.). Eur. J. Agron. 22: 449-458

Corre-Hellou G, Fustec J, Crozat Y (2006): Interspecific competition for soil $\mathrm{N}$ and its interactions with $\mathrm{N}_{2}$ fixation, leaf expansion and crop growth in pea-barley intercrops. Plant Soil 282: 195-208

Crews T E, Peoples M B (2004): Legume versus fertilizer sources of nitrogen: ecological tradeoffs and human needs. Agric. Ecosyst. Environ. 102: 279-297

Dahlmann C, Fragstein N P (2006): Influence of different seed rates, sowing techniques and $\mathrm{N}$ supply on grain yield and quality parameters in intercropping systems. Proceedings of the European Joint Organic Congress, Denmark, 256-257

Dovydaitis V (1992): Baltymingi pašariniai augalai. Vilnius, 189

Hauggaard-Nielsen H, Ambus P, Jensen E S (2003): The comparison of nitrogen use and leaching in sole cropped versus intercropped pea and barley. Nutr. Cycl. Agroecosyst. 65: 289-300

Hauggaard-Nielsen H, Knidsen M T, Jørgensen J R, Jensen E S (2006): Intercropping wheat with pea for improved wheat baking quality. Proceedings of the European Joint Organic Congress, Denmark, 268-269

Hauggaard-Nielsen H, Mundus S, Jensen E S (2009): Nitrogen dynamics following grain legumes and subsequent catch crop and the effects on succeeding cereal crops. Nutr. Cycl. Agroecosyst. 84: 281-291 
Jensen E S (1996): Grain yield, symbiotic $N_{2}$ fixation and interspecific competition for inorganic $\mathrm{N}$ in pea-barley intercrops. Plant Soil 182: 25-38

Jensen E S, Ambus N, Bellostas N, Boisen S, Brisson N, CorreHellou G, Crozat Y, Dahlmann C, Dibet A, Fragstein F, Gooding M, Hauggaard-Nielsen H, Kasyanova E, Launay M, Monti M, Pristeri A (2006): Intercropping of cereals and grain legumes for increased production, weed control, improved product quality and prevention of N-losses in European organic farming systems. Proceedings of the European Joint Organic Congress, Denmark, 180-181

Lauk R, Lauk E (2005): The yields of legume-cereal mixes in years with hight - precipitation vegetation periods. Latvian J. Agron. 8: 281-285

Lauk R., Lauk E. (2008): Pea-oat intercrops are superior to pea-wheat and pea-barley intercrops. Acta Agric. Scand. Section B: Plant Soil Sci. 58: 139-144

Malezieux E, Crozat Y, Dupraz C, Laurans M, Makowski D, Ozier-Lafontane H, Rapidel B, de Tourdonnet S, ValantinMorison M (2009): Mixing plant species in cropping systems: concepts, tools and models. A review. Agron. Sustain. Dev. 29: 43-62

Maikštėniené S, Satkus A (2000): Priešsëjinio dirvos dirbimo būdai ir sëjos gylis žirniams sunkiame priemolyje, Žemdirbystè-Agriculture 69: 71-84
Mariotti M, Masoni A, Ercoli L, Arduini I (2009): Above- and below-ground competition between barley, wheat, lupin and vetch in a cereal and legume intercropping system. Grass Forage Sci. 64: 401-412

Mead R, Willey R W (1980): The concept of 'Land Equivalent Ration' and advantages in yields from intercropping. Exp. Agric. 16: 217-228

Mikić A, Mihailović V, Ćupina B, Đordević V, Stoddard F L (2010): Introduction of novel legume crops in Serbia - White lupin (Lupinus albus). Ratar. Povrt. / Field Veg. Crop Res. 47: 21-26

Petersen R G (1994): Agricultural field experiments: design and analysis. New York, USA, 407

Stoddard F L, Hovinen S, Konnturi M, Lindström K, Nykanen A (2009): Legumes in Finnish agriculture: history, present status and future prospects. Agric. Food Sci. 18: 191-205

Tarakanovas P, Raudonius S (2003): Agronominių tyrimų duomenu statistinè analizè taikant kompiuterines programas ANOVA, STAT, SPLIT-PLOT iš paketo SELEKCIJA ir IRRISTAT. Akademija, 56

Tripolskaja L, Romanovskaja D, Slepetiene A (2008): The effect of various soil and crop management practices on the humus status in sandy loam Haplic Luvisol (in Lithuanian with English abstract). Zemdirbyste-Agriculture 95: 3-18

\title{
Uticaj združene setve stočnog graška i jarih strnih žita na prinos zrna i sadržaj sirovih proteina
}

\author{
Židre Kadžijuljene · Lina Šarunajte · Irena Devejkite \\ Poljoprivredni institut, Litvanski istraživački centar za poljoprivredu i šumarstvo, \\ Instituto al. 1, Akademija, Kedainiai LT-58344, Litvanija
}

Izvod: Prednost združenih useva je u povoljnim biološkim odnosima između useva i njihovog različitog iskorišćenja raspoloživih resursa za rast. Ovaj eksperiment je imao za cilj da istraži uticaj stočnog graška kao združenog useva sa žitaricama na poboljšanje dostupnosti azota žitaricama i sadržaja proteina u zrnu na ilovastom zemljištu u uslovima organske poljoprivrede. Eksperiment je izveden u periodu 2007-2009. u Poljoprivrednom institutu Litvanije u gradu Dotnuva $\left(55^{\circ} 24^{\prime} \mathrm{N}, 23^{\circ} 50\right.$ E). Grašak (Pisum sativum L.) i jara pšenica (Triticum aestivum L.), jari ječam (Hordeum vulgare L.), ovas (Avena sativa L.) i tritikale (x Triticosecale Wittm.) bili su posejani kao združeni usevi 50:50 ili kao čisti usevi. Dobijeni trogodišnji rezultati pokazuju da su produktivnost i kvalitet jarih strnih žita kao čisti ili kao združeni usev zavisili od vrste žita i varirali su u zavisnosti od agrotehničkih uslova u različitim godinama. Produktivnost zrna u nekim slučajevima je procenjena kao viša u združenom usevu, međutim nije bila stabilna u tri godine eksperimenta. Kao združeni usev, grašak je imao pozitivan uticaj na koncentraciju i sadržaj proteina u zrnu žita.

Ključne reči: grašak, jara strna žita, prinos, proteini, združeni usevi 